\title{
Correlates of sport participation among community-dwelling elderly people in Germany: a cross-sectional study
}

\author{
Timo Hinrichs • Ulrike Trampisch • Ina Burghaus • \\ Heinz G. Endres • Renate Klaaßen-Mielke • \\ Anna Moschny • Petra Platen
}

Received: 4 September 2009 /Accepted: 10 March 2010/Published online: 18 April 2010

(C) European Group for Research into Elderly and Physical Activity (EGREPA) 2010

\begin{abstract}
The aims of this study were (1) to analyze the sport participation in a cohort of community-dwelling elderly people in Germany and (2) to evaluate associations between sport participation, sociodemographic factors, cardiovascular risk factors, and health status. In a monitored prospective cohort study (getABI), 6,880 unselected patients $\geq 65$ years have been followed up by 344 general practitioners beginning in 2001. As part of the 5-year follow-up telephone interview, a sample of 1,376 participants was interviewed on sport participation. The association between participation in at least one sporting activity ("sporty" yes/no) during the past week (cycling) or month (other sports) and the following parameters was analyzed by logistic regression: age, sex, immigration
\end{abstract}

\author{
T. Hinrichs $(\bowtie) \cdot$ U. Trampisch $\cdot$ A. Moschny $\cdot$ P. Platen \\ Department of Sports Medicine and Sports Nutrition, \\ Ruhr-University Bochum, \\ 44780 Bochum, Germany \\ e-mail: timo.hinrichs@rub.de \\ U. Trampisch \\ e-mail: ulrike.trampisch@rub.de \\ A. Moschny \\ e-mail: anna.moschny@rub.de \\ P. Platen \\ e-mail: petra.platen@rub.de \\ I. Burghaus • H. G. Endres • R. Klaaßen-Mielke \\ Department of Medical Informatics, Biometry, \\ and Epidemiology, Ruhr-University Bochum, \\ 44780 Bochum, Germany \\ I. Burghaus \\ e-mail: ina.burghaus@rub.de \\ H. G. Endres \\ e-mail: heinz.endres@rub.de \\ R. Klaaßen-Mielke \\ e-mail: renate.klaassen-mielke@rub.de
}

background, education, waist circumference, smoking, selfreported health, history of vascular events, diabetes mellitus, lipometabolic disorder, and arterial hypertension. Analysis of activities $(n=1,304$; median age 76 (70-94) years; $55.1 \%$ women) showed that $27.6 \%$ of participants rode a bicycle during the previous week. During the previous month, $24.9 \%$ of participants did gymnastics or strength training, and $16.5 \%$ swam. Of all participants, $53.8 \%$ were sporty. Multivariate analysis revealed several independent factors to be associated with being sporty $(p<0.05)$ : younger age, male sex, higher education, nonsmoking, better self-reported health, and not being diagnosed with diabetes. Immigration background, waist circumference, history of vascular events, lipometabolic disorder, and hypertension did not show a statistically significant association $(p \geq 0.05)$ with sport participation. Summing up, the most frequently performed sporting activities were cycling, gymnastics or strength training, and swimming. Sport participation was associated with, for example, age and sex.

Keywords Aged · Physical activity · Sports · Health status · Vascular diseases $\cdot$ Epidemiology

\section{Introduction}

The population of many industrialized countries is aging. In Germany, the number of people aged 65 and older will rise dramatically within the next decades: while nearly 16 million people $(19 \%$ of the whole German population) were at that age in 2005, the number will grow to over 22 million people ( $29 \%$ of the whole German population) in 2030 [16]. Regular physical activity is important for the old age group, not only for the beneficial effects on conditions such as diabetes and cardiovascular disease but also for the maintenance of 
mobility, independent living, and well-being. A strong body of scientific evidence shows that physical activity can help older people maintain their health [18, 29]. Because of all known benefits, current recommendations encourage physical activity on most or all days of the week. A multidimensional activity program including endurance, strength, balance, and flexibility training is generally considered optimal for older adults [27, 29].

Sporting activities are an important subset of overall physical activity. They are usually structured and performed on a regular basis. Most sporting activities, e.g., swimming, ball games, or cycling, combine endurance, strength, balance, and flexibility training. Cross-sectional and interventional studies support that all those basic motor skills increase by regular training even in very old people and in elderly patients with chronic diseases [15, 21, 22, 24, 28]. Sporting activities may thus contribute toward meeting the physical activity recommendations.

Due to the demographic change, considerable public effort is being devoted to preventing the negative health and economic consequences [32] of sedentary behavior in seniors by promoting sport participation. However, data on sport participation of elderly people in Germany aged over 70 years are scarce. According to the German National Health Interview 2003, participation in at least $2 \mathrm{~h}$ of sporting activities per week in the age group of 30-39 years is $45.6 \%$ in men and $32.9 \%$ in women. In the age group of $70-79$ years, participation drops to $29.9 \%$ in men and $22.2 \%$ in women. Only $15.5 \%$ of men and $17.5 \%$ of women aged 80 years or older engage in at least $2 \mathrm{~h}$ of sports per week [33]. Unfortunately, little is known about the specific aspects of the performed activities (e.g., kind, frequency, intensity, or duration) and about the reasons for nonparticipation.

Consequently, the first aim of this study was to perform an analysis of the participation in sporting activities in a cohort of community-dwelling elderly people in Germany. The second aim was to analyze associations between participation in sporting activities, sociodemographic factors, cardiovascular risk factors, and health status.

\section{Methods}

Study design and participants

The "German epidemiological study on ankle brachial index" (getABI) is a large-scale epidemiological trial with a cross-sectional part and a longitudinal part. The methods and design of the study have been described elsewhere in greater detail [14, 19]. Briefly, 34 vascular physicians across Germany trained and supervised 344 representative general practitioners in their vicinity. An assessment of primary care attendees, irrespective of their reason for seeing the doctor, was conducted in a prespecified week in October 2001. An average of 20 (maximum 25) eligible patients per practice fulfilling the inclusion criteria (age $\geq$ 65 years, patient being legally competent and able to cooperate appropriately, and providing written informed consent) were recruited over this week. The only exclusion criterion was life expectancy $\leq 6$ months. A total of 6,880 patients were included in the study. Results reported in this paper mostly refer to the cross-sectional part of the 5-year follow-up. As part of the 5-year follow-up telephone interview, a sample of 1,376 participants was interviewed on sport participation. The protocol of getABI was approved by the University of Heidelberg (Germany) Ethics Committee. All patients gave written informed consent. The study was conducted according to the "Good Epidemiological Practice" recommendations issued by the "German Working Group Epidemiology" [2].

\section{Outcome}

\section{Sport participation}

Participation in sporting activities was assessed as part of the 5-year follow-up telephone interview using a modified version of the "Freiburger" questionnaire [17]. The activities asked and the summarized total time devoted to these activities are listed in Tables 2 and 3. The total time was given in three categories depending on the stated activity (either about $15 \mathrm{~min}$, about $30 \mathrm{~min}$, about $60 \mathrm{~min}$ or longer during the last week; or about $1 \mathrm{~h}$, about $2-3 \mathrm{~h}$, about $4 \mathrm{~h}$ or longer during the last month).

The main outcome for the logistic regression analysis was the binary parameter sport participation ("sporty"): yes or no. Participants who performed at least one sporting activity during the week (cycling) or the month (other sports) prior to the interview were defined as sporty. The recall of different time periods for cycling and other sports is a limitation of the "Freiburger" questionnaire. Cycling was defined as a sporting activity independent of the purpose (to run errands, for leisure, on bicycle tours, or on a stationary bicycle). This definition was based on the consideration that, for elderly people, cycling is a demanding task that requires not only a certain endurance capacity but also coordination, balance, and reaction speed. Looking at the metabolic requirements, Ainsworth et al. assign 4.0 metabolic equivalents even to "bicycling, $<10 \mathrm{mph}$, to work or for pleasure" [1]. In contrast, walking either for leisure or to run errands was considered an everyday activity (not a sporting activity) because even for elderly people it does not require special motor skills and is usually of less than moderate intensity [1]. 


\section{Covariables}

\section{Sociodemographic variables}

The participants' sex and date of birth were documented by the general practitioner at baseline. For the definition of the variable "education level," the participants' highest graduation (no graduation/comprehensive school (Hauptschulabschluss)/high school (Realschulabschluss or Mittlere Reife)/university entrance qualifications (Fachabitur or Abitur)) was assessed by the general practitioner at baseline. The country of birth was evaluated by telephone interview (5-year follow-up).

\section{Cardiovascular risk factors}

Waist circumference was measured in the general practitioner's practice by standard protocol at the 3- and the 5-year follow-up of getABI. Waist circumference at 5-year follow-up was used for analysis. If this value was missing, waist circumference at 3-year follow-up was used. The current smoking status was documented at baseline (nonsmoker/former smoker/current smoker).

\section{Health status}

Both subjective and objective measures of health status were used: self-reported health status, report of the general practitioner, and blood test results.

Self-reported general health was assessed by telephone interview (5-year follow-up) by the use of the Short-Form 8 Health Survey (SF-8 ${ }^{\text {TM }}$ 4-week recall version). The instrument yields an eight-part profile of functional health and well-being. Two SF-8 composites can be calculated: the SF-8 physical component score (PCS) and the SF-8 mental component score (MCS). These scores are linear combinations of the eight items based on their respective importance for physical functioning and mental functioning. Higher scores represent better health status. The survey has demonstrated good reliability and validity [38].

The general practitioners documented the following vascular events at the beginning and throughout the trial (until follow-up at 5 years): cardiovascular events (myocardial infarction, cardiac revascularisation), cerebrovascular events (stroke, revascularization at carotids), and peripheral arterial events (amputation, peripheral revascularization, intermittent claudication).

Subjects were defined to have diabetes mellitus if they had been assigned the clinical diagnosis by their physician, if they were receiving any antidiabetic medication (insulin or oral), or if their HbAlc (glycosylated hemoglobin) was $\geq 6.5 \%$. Subjects were defined to have a lipometabolic disorder if they had been assigned the clinical diagnosis by their physician, if they were receiving cholesterolsynthesizing enzyme (CSE) inhibitors or fibrates, if their serum total cholesterol was $\geq 200 \mathrm{mg} / \mathrm{dl}$, or if their serum triglycerides were $\geq 150 \mathrm{mg} / \mathrm{dl}$. Subjects were defined to have arterial hypertension if they had been assigned the clinical diagnosis by their physician or if they were receiving an angiotensin-converting enzyme (ACE) inhibitor or an angiotensin type 1 receptor (AT1) antagonist or diuretics. Diabetes mellitus, lipometabolic disorder, and arterial hypertension classifications were done at baseline.

\section{Statistical analysis}

Statistical analyses were performed with SAS version 9.1 (SAS Institute Inc., Cary, NC, USA). A logistic regression analysis (both univariate and adjusted for covariables) was performed to assess the association between the main outcome sport participation (sporty yes/no) and the following binary sociodemographic parameters, cardiovascular risk factors, and parameters of health status: age $(\leq>>$ median age (76 years)), sex (female/male), birthplace (inside/outside Germany), graduation (at least/less than university entrance qualifications (Fachabitur)), waist circumference (men $</ \geq 102 \mathrm{~cm}$; women $</ \geq 88 \mathrm{~cm}$ ) [20], smoking status (smoking/not smoking), SF-8 PCS $(>1 \leq$ median PCS (48.3)), SF-8 MCS ( $>/ \leq$ median MCS (55.4)), history of (at least one) cardiovascular event (yes/no or unknown), history of (at least one) cerebrovascular event (yes/no or unknown), history of (at least one) peripheral arterial event (yes/no or unknown), diabetes mellitus (yes/ no or unknown), lipometabolic disorder (yes/no or unknown), and arterial hypertension (yes/no or unknown).

Persons with missing values in one of the following variables were excluded from all analyses: sporting activities, age, sex, birthplace, graduation, waist circumference, SF-8 PCS, SF-8 MCS, walking (leisure/errands). In case of contradictory answers, data were analyzed as obtained. The level of significance was set at $p<0.05$ for all analyses.

\section{Results}

\section{Participants}

Of the 1,376 participants, 72 were excluded from analyses because of incomplete data. A total of 1,304 participants (median age 76 (70-94) years; 55.1\% women) were included in the analyses. Three of the sporty participants answered "yes" when they were asked if they performed a sporting activity (in general) during the past month, but they did not specify any of the activities listed in Table 3 (as well as cycling during the last week). Participant characteristics are shown in Table 1. 
Table 1 Participant characteristics at 5-year follow-up

\begin{tabular}{|c|c|c|c|c|c|c|}
\hline & Number & Percent & Mean \pm SD & Minimum & Median & Maximum \\
\hline Age (years) & 1,304 & & $76.4 \pm 4.5$ & 70 & 76 & 94 \\
\hline Median age or younger ( $\leq 76$ years) & 726 & 55.7 & & & & \\
\hline Older than median age ( $>76$ years) & 578 & 44.3 & & & & \\
\hline Sex & 1,304 & & & & & \\
\hline Female & 718 & 55.1 & & & & \\
\hline Male & 586 & 44.9 & & & & \\
\hline Birthplace & 1,304 & & & & & \\
\hline Outside Germany & 121 & 9.3 & & & & \\
\hline Germany & 1,183 & 90.7 & & & & \\
\hline Education level (graduation) & 1,304 & & & & & \\
\hline Lower than university entrance qualifications $\mathrm{s}^{\mathrm{a}}$ & 1,080 & 82.8 & & & & \\
\hline At least university entrance qualifications $\mathrm{s}^{\mathrm{a}}$ & 224 & 17.2 & & & & \\
\hline Waist circumference $(\mathrm{cm})^{\mathrm{b}}$ & 1,304 & & $97.8 \pm 11.8$ & 67 & 98 & 147 \\
\hline$M e n<102 \mathrm{~cm}$; women $<88 \mathrm{~cm}$ & 503 & 38.6 & & & & \\
\hline$M e n \geq 102 \mathrm{~cm}$; women $\geq 88 \mathrm{~cm}$ & 801 & 61.4 & & & & \\
\hline Currently smoking (baseline) & 1,304 & & & & & \\
\hline No & 1,210 & 92.8 & & & & \\
\hline Yes & 94 & 7.2 & & & & \\
\hline SF-8 physical component score (PCS) & 1,304 & & $46.8 \pm 8.7$ & 10.3 & 48.3 & 66.4 \\
\hline Higher than median PCS $(>48.3)$ & 651 & 49.9 & & & & \\
\hline Median PCS or lower $(\leq 48.3)$ & 653 & 50.1 & & & & \\
\hline SF-8 mental component score (MCS) & 1,304 & & $53.2 \pm 7.4$ & 20.5 & 55.4 & 66.3 \\
\hline Higher than median MCS $(>55.4)$ & 652 & 50.0 & & & & \\
\hline Median MCS or lower $(\leq 55.4)$ & 652 & 50.0 & & & & \\
\hline Cardiovascular event $^{\mathrm{c}}$ & 1,304 & & & & & \\
\hline No/unknown & 1,109 & 85.0 & & & & \\
\hline Yes & 195 & 15.0 & & & & \\
\hline Cerebrovascular event ${ }^{\mathrm{d}}$ & 1,304 & & & & & \\
\hline No/unknown & 1,238 & 94.9 & & & & \\
\hline Yes & 66 & 5.1 & & & & \\
\hline Peripheral arterial event ${ }^{\mathrm{e}}$ & 1,304 & & & & & \\
\hline No/unknown & 1,161 & 89.0 & & & & \\
\hline Yes & 143 & 11.0 & & & & \\
\hline Diabetes mellitus ${ }^{\mathrm{f}}$ & 1,304 & & & & & \\
\hline No/unknown & 1,038 & 79.6 & & & & \\
\hline Yes & 266 & 20.4 & & & & \\
\hline Lipometabolic disorder ${ }^{\mathrm{g}}$ & 1,304 & & & & & \\
\hline No/unknown & 207 & 15.9 & & & & \\
\hline Yes & 1,097 & 84.1 & & & & \\
\hline Arterial hypertension ${ }^{\mathrm{h}}$ & 1,304 & & & & & \\
\hline No/unknown & 460 & 35.3 & & & & \\
\hline Yes & 844 & 64.7 & & & & \\
\hline Sporty $^{\mathrm{i}}$ & 1,304 & & & & & \\
\hline No & 602 & 46.2 & & & & \\
\hline Yes & 702 & 53.8 & & & & \\
\hline
\end{tabular}

\section{$S D$ standard deviation}

${ }^{\text {a }}$ Fachabitur

${ }^{\mathrm{b}}$ Waist circumference at 5-year follow-up is used; if it is missing, waist circumference at 3-year follow-up is used

c "Cardiovascular event" is defined as the incidence of (at least) one of the following events until follow-up at 5 years: myocardial infarction or cardiac revascularization

$\mathrm{d}$ "Cerebrovascular event" is defined as the incidence of (at least) one of the following events until follow-up at 5 years: stroke or revascularization at carotids

e "Peripheral arterial event" is defined as the incidence of (at least) one of the following events/symptoms until follow-up at 5 years: amputation, peripheral revascularization, or intermittent claudication

${ }^{\mathrm{f}}$ Subjects were defined to have diabetes mellitus if they had been assigned the clinical diagnosis by their physician, if they were receiving any antidiabetic medication (insulin or oral), or if their HbAlc (glycosylated hemoglobin) was $\geq 6.5 \%$ at baseline

${ }^{g}$ Subjects were defined to have a lipometabolic disorder if they had been assigned the clinical diagnosis by their physician, if they were receiving CSE inhibitors or fibrates, if their serum total cholesterol was $\geq 200 \mathrm{mg} / \mathrm{dl}$, or if their serum triglycerides were $\geq 150 \mathrm{mg} / \mathrm{dl}$ at baseline

${ }^{\mathrm{h}}$ Subjects were defined to have arterial hypertension if they had been assigned the clinical diagnosis by their physician or if they were receiving ACE inhibitor or AT1 antagonist or diuretics at baseline

${ }^{\mathrm{i}}$ Sporty is defined as participation in at least one sporting activity during the week (cycling) or the month (other sports) prior to the interview 
Analysis of sporting activities

The analysis of sporting activities showed that $27.6 \%$ of all participants rode a bicycle during the week prior to the interview. Of all participants, $12.7 \%$ rode a bicycle to run errands, and $18.4 \%$ did a bicycle tour or rode on a stationary bicycle. During the previous month, $24.9 \%$ of participants did gymnastics or strength training, 16.5\% swam, and $6.2 \%$ bowled or danced. Every other sporting activity was performed by less than $5 \%$ of participants during the previous month (see Tables 2 and 3). Of all participants, $53.8 \%$ reported to have performed at least one sporting activity during the week (cycling) or month (other sports) prior to the interview (i.e., were sporty). Of all participants, $83.7 \%$ ran errands on foot and $74.3 \%$ went for a leisure walk during the previous week.

\section{Logistic regression analysis}

The results of the multivariate regression analysis are shown in Table 4. In the adjusted model, age older than median age (odds ratio (OR) $0.58 ; 95 \%$ confidence interval $(95 \% \mathrm{CI})$ $0.46-0.73$ ) and current smoking (OR 0.43 ; 95\% CI $0.27-0.67$ ) were the only two factors associated with an approximate halving of the chance of being sporty. Other less meaningful factors were diabetes mellitus (OR 0.70; 95\% CI 0.52-0.93), as well as low self-reported (SF-8) physical (OR 0.69; 95\% CI 0.55-0.87) and mental health (OR 0.76; 95\% CI 0.60-0.95). On the other hand, the two factors higher educational level (OR 1.39; 95\% CI 1.02-1.90) and male sex (OR $1.34 ; 95 \%$ CI 1.04-1.72) increased the chance of being sporty.

Immigration background, waist circumference, history of vascular events, lipometabolic disorder, and arterial hypertension did not show a statistically significant association with participation in sporting activities.

\section{Discussion}

The three most common types of active sport practiced by getABI participants were riding a bicycle, gymnastics or strength training, and swimming. In the literature, comparable data on activity patterns of elderly people at a population level are scarce. Due to varying evaluation methods, data from different surveys have to be compared cautiously (see Table 5).

According to data of the US "Behavioral Risk Factor Surveillance System" (BRFSS) of the Centers for Disease Control and Prevention 2004, 36\% of people 75 years or older do not participate in any leisure time physical activity [10]. The BRFSS of the year 2000 asked adults aged 65 years and older to report the two physical activities or exercises that they had participated in the most during the past month. Nearly $70 \%$ of physically active respondents reported walking as the type of physical activity or exercise they had spent the most time doing during the past month. The next most common activities in older adults in the USA were gardening (reported by $9.6 \%$ of people), cycling $(3.9 \%)$, home exercises $(3.3 \%)$, and golf $(2.8 \%)$. About $12 \%$ of older adults reported participating in other types of activities, which included aerobics classes, swimming, weight lifting, running/jogging, and playing tennis [9]. At first sight, the participation in sporting activities seems to be lower in older US adults than in the getABI cohort. However, this may be due to the fact that the US adults were only given the possibility to report the two physical activities that they had participated in the most. This can lead to an underestimation of participation in activities. In the getABI cohort, all sporting activities were recorded.

Zizzi et al. [39] studied the physical activity habits in a community sample of older adults $(N=470)$ in Appalachia (USA). The participants were asked whether they had performed the respective activity in a typical week during the past month. The comparison to the getABI sample reveals that cycling seems to be more popular in Germany and that brisk walking for exercise and playing golf seem to be more popular in Appalachia. Older people in Germany seem to like walking for leisure, but walking briskly for exercise is not common at all. In Australia, $53.4 \%$ of all persons aged $65-74$ and $35.7 \%$ of all persons aged 75 and over walked for exercise in the 2 weeks prior to the National Health Survey interview 2004/2005. In both age

Table 2 Participation in "riding a bicycle" during the week prior to the interview and summarized duration $(n=1,304 ; 586 \mathrm{males}(\mathrm{m}) ; 718$ females (f))

\begin{tabular}{|c|c|c|c|c|c|c|}
\hline Kind of activity & Sex & \multicolumn{2}{|c|}{ Participation $(\%)$} & About $15 \mathrm{~min}(\%)$ & $\begin{array}{l}\text { About } \\
\text { 30min (\%) }\end{array}$ & $\begin{array}{l}\text { About } 60 \mathrm{~min} \\
\text { or longer }(\%)\end{array}$ \\
\hline Riding a bicycle & $\begin{array}{l}\mathrm{m} \\
\mathrm{f}\end{array}$ & $\begin{array}{l}34.5 \\
22.0\end{array}$ & 27.6 & Not further specified & & \\
\hline Riding a bicycle to run errands & $\begin{array}{l}\mathrm{m} \\
\mathrm{f}\end{array}$ & $\begin{array}{l}15.2 \\
10.7\end{array}$ & 12.7 & 0.6 & 3.8 & 8.3 \\
\hline Riding a stationary bicycle or on bicycle tours & $\begin{array}{l}\mathrm{m} \\
\mathrm{f}\end{array}$ & $\begin{array}{l}24.4 \\
13.5\end{array}$ & 18.4 & 2.0 & 3.2 & 13.2 \\
\hline
\end{tabular}


Table 3 Participation in activities during the month prior to the interview and summarized duration $(n=1,304 ; 586$ males (m); 718 females (f))

\begin{tabular}{|c|c|c|c|c|c|c|}
\hline \multirow{2}{*}{$\frac{\text { Kind of activity }}{\text { Gymnastics or strength training }}$} & \multirow{2}{*}{$\begin{array}{l}\text { Sex } \\
\mathrm{m}\end{array}$} & \multicolumn{2}{|c|}{ Participation (\%) } & \multirow{2}{*}{$\frac{\text { About } 1 \mathrm{~h}(\%)}{2.5}$} & \multirow{2}{*}{$\frac{\text { About } 2-3 \mathrm{~h}(\%)}{5.1}$} & \multirow{2}{*}{$\frac{\text { About } 4 \mathrm{~h} \text { or longer }(\%)}{17.3}$} \\
\hline & & $\begin{array}{l}20.5 \\
28.6\end{array}$ & 24.9 & & & \\
\hline Swimming & $\begin{array}{l}\mathrm{m} \\
\mathrm{f}\end{array}$ & $\begin{array}{l}18.4 \\
14.9\end{array}$ & 16.5 & 6.1 & 5.4 & 5.1 \\
\hline Dancing or bowling & $\begin{array}{l}\mathrm{m} \\
\mathrm{f}\end{array}$ & $\begin{array}{l}8.9 \\
4.0\end{array}$ & 6.2 & 0.7 & 2.6 & 2.9 \\
\hline Brisk walking & $\begin{array}{l}\mathrm{m} \\
\mathrm{f}\end{array}$ & $\begin{array}{l}2.7 \\
2.9\end{array}$ & 2.8 & 0.3 & 0.5 & 2.1 \\
\hline Jogging or running & $\begin{array}{l}\mathrm{m} \\
\mathrm{f}\end{array}$ & $\begin{array}{l}2.0 \\
0.1\end{array}$ & 1.0 & 0.5 & 0.2 & 0.4 \\
\hline Ball games like tennis or football & $\begin{array}{l}\mathrm{m} \\
\mathrm{f}\end{array}$ & $\begin{array}{l}4.1 \\
0.7\end{array}$ & 2.2 & 0.4 & 0.7 & 1.2 \\
\hline Skiing (downhill or cross country) & $\begin{array}{l}\mathrm{m} \\
\mathrm{f}\end{array}$ & $\begin{array}{l}1.5 \\
0.3\end{array}$ & 0.8 & 0.0 & 0.3 & 0.5 \\
\hline Other strenuous sports & $\begin{array}{l}\mathrm{m} \\
\mathrm{f}\end{array}$ & $\begin{array}{l}2.2 \\
0.6\end{array}$ & 1.3 & 0.2 & 0.2 & 0.9 \\
\hline Other less strenuous sports & $\begin{array}{l}\mathrm{m} \\
\mathrm{f}\end{array}$ & $\begin{array}{l}2.6 \\
2.1\end{array}$ & 2.3 & 0.3 & 0.5 & 1.5 \\
\hline
\end{tabular}

groups, about $60 \%$ of the persons who walked for exercise did so more than seven times within those 2 weeks [3].

Analyses of the "Allied Dunbar National Fitness Survey" and the "Health Education Authority National Survey of Activity and Health" (UK, $N=3,078$ ) revealed that "exercises", cycling, social dancing, and swimming were the four most popular sporting activities among adults aged 50 years and above. Of those activities, exercises showed the least decrease with age [36].

The "Taking Part: England's Survey of Culture, Leisure and Sport" is a national survey of private households in England. The survey examined the participation in active sport in 2005/2006 [34]. For the annual report 2005/2006, Rowe and Bibby defined participation as physical engagement in at least one type of active sport during the past 12 months. The data showed that $69 \%$ of all adults had participated in an active sport. The participation decreased with age, dropping from $82.6 \%$ in the age group 2544 years to $45.3 \%$ in the age group 65-74 years and to $21.8 \%$ in the age group 75 years and older. Males $(74.4 \%)$ had higher rates of participation than females $(64.5 \%)$. Of those who had not participated in any active sport during the past 12 months, "health isn't good enough" was the main reason for nonparticipation. In August 2008, further more detailed data on sport participation from the "Taking Part" survey 2005/2006 have been published on the internet [13]. These data also include the types of sports and the participation during the past 4 weeks, which makes the data comparable to the getABI data. Among all adults in the "Taking Part" survey, the most common type of active sport participated in during the past 4 weeks was swimming or diving indoors $(15.7 \%)$, followed by health, fitness, gym or conditioning activities (13.8\%), and recreational cycling $(9.7 \%)$. Unfortunately, the participation in different sports is not presented separately for different age groups in the report of the "Taking Part" survey. By comparing the preferred activities of England's adults with those of the getABI cohort, it can be stated that the three most popular sporting activities in both populations are swimming, cycling, and conditioning activities.

A logistic regression analysis in the getABI cohort showed that more elderly men than women participate in sporting activities. This is in line with findings of previous investigations [10, 33].

Participation in sporting activities was negatively associated with poor self-reported health status and with the diagnosis "diabetes mellitus". An association with previous vascular events, with the presence of a lipometabolic disorder or arterial hypertension, could not be shown. Due to the cross-sectional character of the study, no conclusions on any causality or the direction of the causality between participation in sporting activities and health status can be drawn. On the one hand, there is evidence that a fit and active way of life improves and preserves health and function in older individuals [5]. On the other hand, limited health is known to be the most important barrier to sport participation in elderly people [12, 26, 34].

In the present study, age has been demonstrated to be independently associated to participation in sporting activities. Older people seem to stop participating in activities independent of their health status even after the age of 70 years. In this context, it might be useful to consider old 
Table 4 Multivariate analysis of association between sport participation, sociodemographic factors, cardiovascular risk factors, and health status $(n=1,304)$

\begin{tabular}{|c|c|c|c|c|c|c|}
\hline & & All $(n)$ & Sporty $^{\mathrm{a}}(\%)$ & $\begin{array}{l}\text { OR univariate } \\
(95 \% \mathrm{CI})\end{array}$ & $\begin{array}{l}\text { OR multivariate } \\
(95 \% \mathrm{CI})\end{array}$ & $\begin{array}{l}p \text { value } \\
\text { multivariate }\end{array}$ \\
\hline \multirow[t]{2}{*}{ Age } & $\begin{array}{l}\text { Median age or younger } \\
\text { ( } \leq 76 \text { years })\end{array}$ & 726 & 59.8 & Reference & & \\
\hline & $\begin{array}{l}\text { Older than median age } \\
(>76 \text { years })\end{array}$ & 578 & 46.4 & $0.58(0.47-0.73)$ & $0.58(0.46-0.73)$ & $<0.001$ \\
\hline \multirow[t]{2}{*}{ Sex } & Female & 718 & 50.1 & Reference & & \\
\hline & Male & 586 & 58.4 & $1.39(1.12-1.74)$ & $1.34(1.04-1.72)$ & 0.022 \\
\hline \multirow[t]{2}{*}{ Birthplace } & Outside Germany & 121 & 47.9 & Reference & & \\
\hline & Germany & 1,183 & 54.4 & $1.30(0.89-1.89)$ & $1.30(0.89-1.92)$ & 0.180 \\
\hline \multirow[t]{2}{*}{$\begin{array}{l}\text { Education level } \\
\text { (graduation) }\end{array}$} & $\begin{array}{l}\text { Lower than university } \\
\text { entrance qualifications }\end{array}$ & 1,080 & 52.2 & Reference & & \\
\hline & $\begin{array}{l}\text { At least university entrance } \\
\text { qualifications } \mathrm{s}^{\mathrm{b}}\end{array}$ & 224 & 61.6 & 1.47 (1.09-1.97) & $1.39(1.02-1.90)$ & 0.036 \\
\hline \multirow[t]{2}{*}{ Waist circumference ${ }^{\mathrm{c}}$} & $\begin{array}{l}\text { Men }<102 \mathrm{~cm} \text {; women }< \\
\quad 88 \mathrm{~cm}\end{array}$ & 503 & 57.1 & Reference & & \\
\hline & $\begin{array}{l}\text { Men } \geq 102 \mathrm{~cm} ; \text { women } \geq \\
88 \mathrm{~cm}\end{array}$ & 801 & 51.8 & $0.81(0.65-1.01)$ & $0.93(0.73-1.19)$ & 0.563 \\
\hline \multirow{2}{*}{$\begin{array}{l}\text { Currently smoking } \\
\text { (baseline) }\end{array}$} & No & 1,210 & 54.9 & Reference & & \\
\hline & Yes & 94 & 40.4 & $0.56(0.36-0.86)$ & $0.43(0.27-0.67)$ & $<0.001$ \\
\hline \multirow[t]{2}{*}{$\begin{array}{l}\text { SF-8 physical component } \\
\text { score (PCS) }\end{array}$} & $\begin{array}{l}\text { Higher than median PCS } \\
(>48.3)\end{array}$ & 651 & 60.1 & Reference & & \\
\hline & $\begin{array}{l}\text { Median PCS or lower } \\
(\leq 48.3)\end{array}$ & 653 & 47.6 & $0.61(0.49-0.75)$ & $0.69(0.55-0.87)$ & 0.002 \\
\hline \multirow[t]{2}{*}{$\begin{array}{l}\text { SF-8 mental component } \\
\text { score (MCS) }\end{array}$} & $\begin{array}{l}\text { Higher than median MCS } \\
(>55.4)\end{array}$ & 652 & 58.1 & Reference & & \\
\hline & $\begin{array}{l}\text { Median MCS or lower } \\
(\leq 55.4)\end{array}$ & 652 & 49.5 & $0.71(0.57-0.88)$ & $0.76(0.60-0.95)$ & 0.018 \\
\hline \multirow[t]{2}{*}{ Cardiovascular event $^{\mathrm{d}}$} & No/unknown & 1,109 & 54.4 & Reference & & \\
\hline & Yes & 195 & 50.8 & $0.87(0.64-1.17)$ & $0.82(0.58-1.15)$ & 0.256 \\
\hline \multirow[t]{2}{*}{ Cerebrovascular event ${ }^{\mathrm{e}}$} & No/unknown & 1,238 & 54.1 & Reference & & \\
\hline & Yes & 66 & 48.5 & $0.80(0.49-1.31)$ & $0.88(0.53-1.48)$ & 0.640 \\
\hline \multirow{2}{*}{$\begin{array}{l}\text { Peripheral arterial } \\
\text { event }^{\mathrm{f}}\end{array}$} & No/unknown & 1,161 & 53.9 & Reference & & \\
\hline & Yes & 143 & 53.1 & $0.97(0.68-1.37)$ & $1.35(0.92-1.96)$ & 0.125 \\
\hline \multirow[t]{2}{*}{ Diabetes mellitus ${ }^{\mathrm{g}}$} & No/unknown & 1,038 & 55.7 & Reference & & \\
\hline & Yes & 266 & 46.6 & $0.70(0.53-0.91)$ & $0.70(0.52-0.93)$ & 0.013 \\
\hline \multirow{2}{*}{$\begin{array}{l}\text { Lipometabolic } \\
\text { disorder }^{\mathrm{h}}\end{array}$} & No/unknown & 207 & 57.0 & Reference & & \\
\hline & Yes & 1,097 & 53.2 & $0.86(0.64-1.16)$ & $0.99(0.72-1.36)$ & 0.943 \\
\hline \multirow[t]{2}{*}{ Arterial hypertension ${ }^{\mathrm{i}}$} & No/unknown & 460 & 58.3 & Reference & & \\
\hline & Yes & 844 & 51.4 & $0.76(0.60-0.95)$ & $0.84(0.66-1.08)$ & 0.168 \\
\hline
\end{tabular}

$O R$ odds ratio as a result of a logistic regression (multivariate odds ratios were adjusted for all other variables in the table), $C I$ confidence interval

${ }^{\text {a }}$ Sporty is defined as participation in at least one sporting activity during the week (cycling) or the month (other sports) prior to the interview

${ }^{\mathrm{b}}$ Fachabitur

${ }^{\mathrm{c}}$ Waist circumference at 5-year follow-up is used; if it is missing, waist circumference at 3-year follow-up is used

$\mathrm{d}$ "Cardiovascular event" is defined as the incidence of (at least) one of the following events until follow-up at 5 years: myocardial infarction or cardiac revascularization

e "Cerebrovascular event" is defined as the incidence of (at least) one of the following events until follow-up at 5 years: stroke or revascularization at carotids

f "Peripheral arterial event" is defined as the incidence of (at least) one of the following events/symptoms until follow-up at 5 years: amputation, peripheral revascularization, or intermittent claudication

${ }^{\mathrm{g}}$ Subjects were defined to have diabetes mellitus if they had been assigned the clinical diagnosis by their physician, if they were receiving any antidiabetic medication (insulin or oral), or if their $\mathrm{HbAlc}$ (glycosylated hemoglobin) was $\geq 6.5 \%$ at baseline

${ }^{\mathrm{h}}$ Subjects were defined to have a lipometabolic disorder if they had been assigned the clinical diagnosis by their physician, if they were receiving CSE inhibitors or fibrates, if their serum total cholesterol was $\geq 200 \mathrm{mg} / \mathrm{dl}$, or if their serum triglycerides were $\geq 150 \mathrm{mg} / \mathrm{dl}$ at baseline

${ }^{\mathrm{i}}$ Subjects were defined to have arterial hypertension if they had been assigned the clinical diagnosis by their physician or if they were receiving ACE inhibitor or AT1 antagonist or diuretics at baseline 

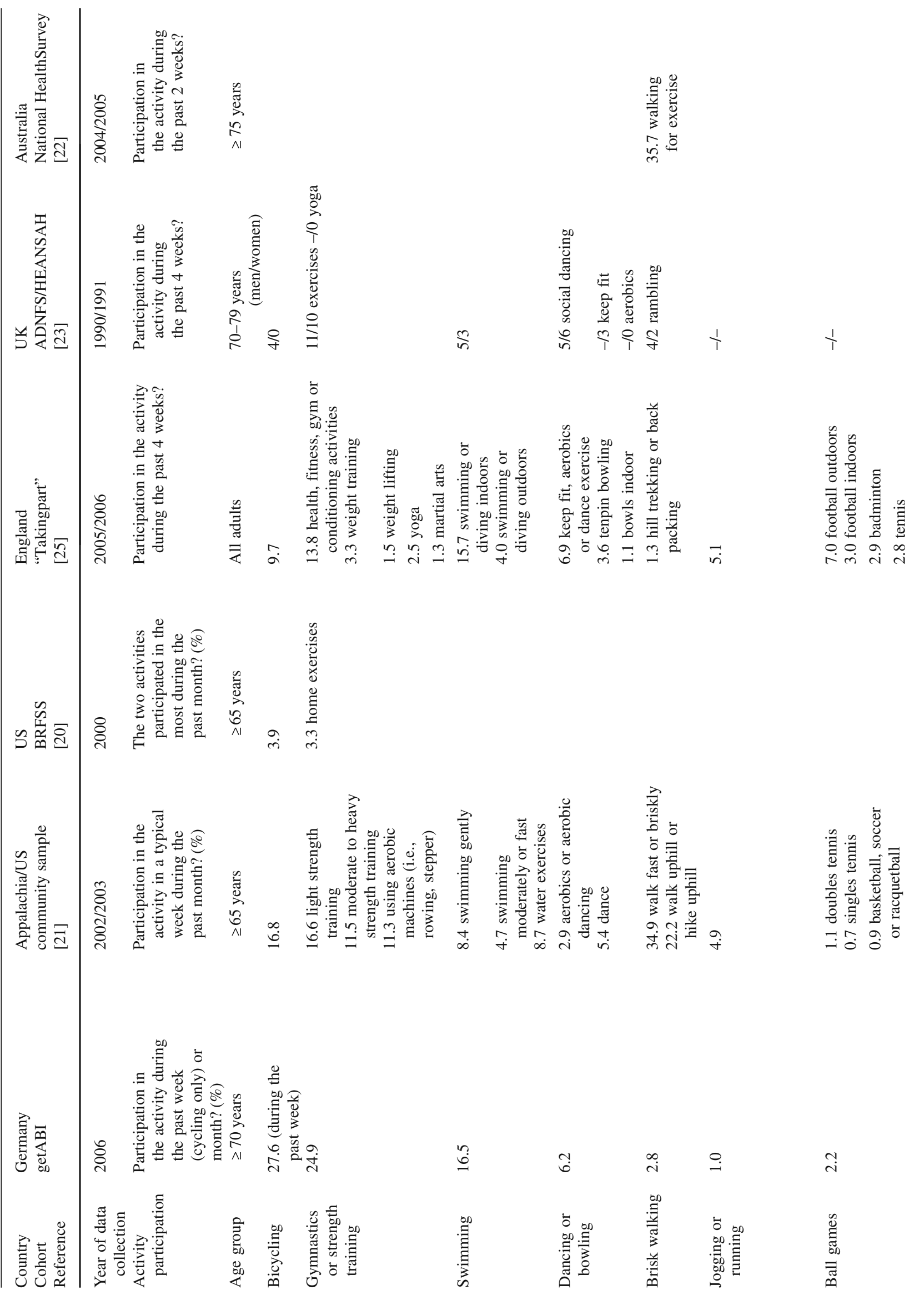


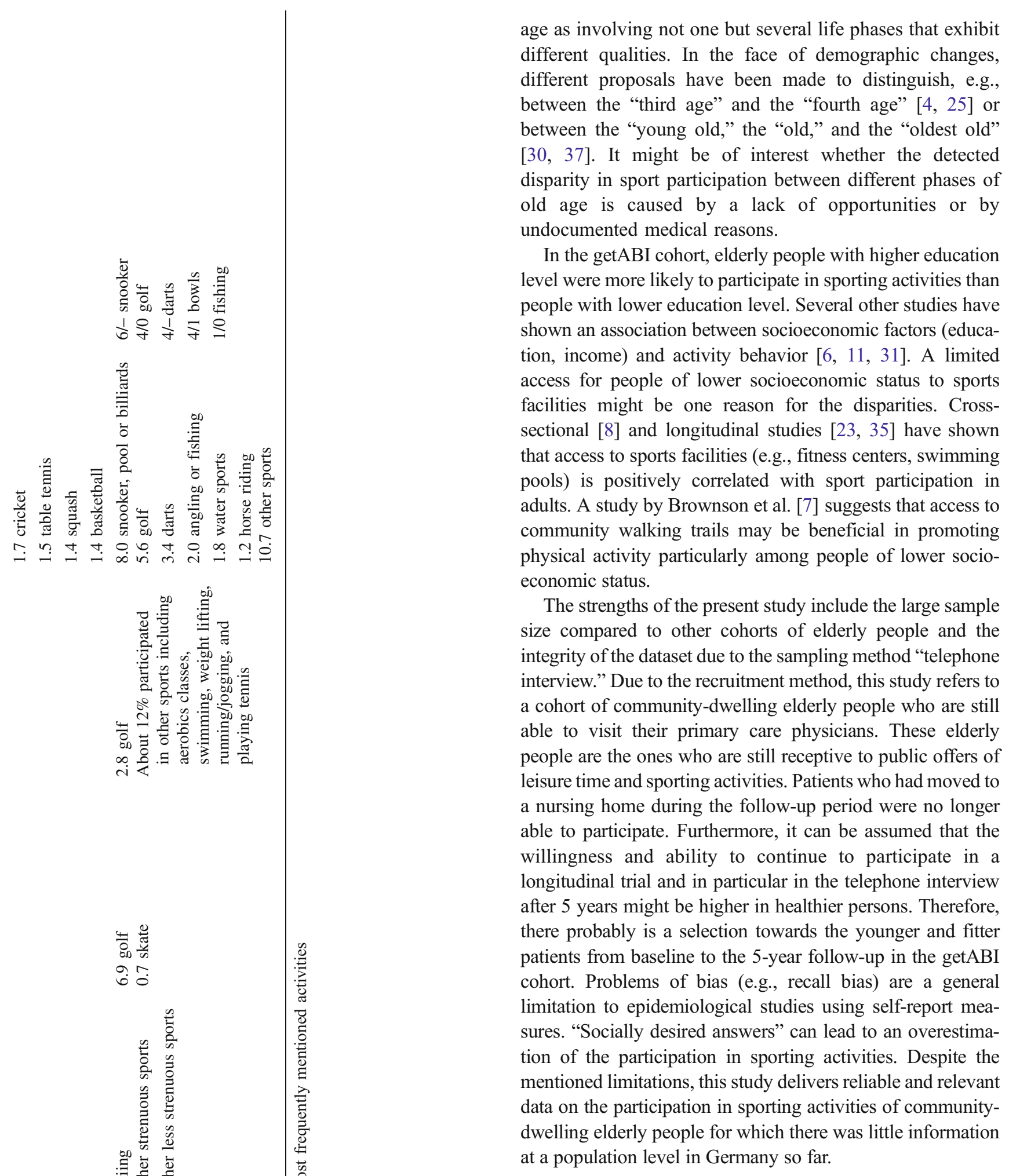

\section{Conclusions}

Only a small percentage of older community-dwelling adults did sporting activities other than cycling, gymnastics, strength training, swimming, bowling, or dancing. The 
study identified several independent factors (e.g., age, sex, self-reported health) to be associated with sport participation. Tailoring sports programs to the needs and abilities of specific subgroups (e.g., highly aged, women) might help to reduce the presented disparities. The effects of such measures should be evaluated.

Acknowledgement From 2001 to 2007, getABI has been supported by an unrestricted educational grant from Sanofi-Aventis, Berlin, Germany. Since 2007, the trial is funded by the German Federal Ministry of Education and Research. The present study has been conducted within the research cooperation PRISCUS ("Prerequisites for a new health care model for elderly people with multimorbidity").

Competing interests The authors declare that they have no competing interests.

\section{References}

1. Ainsworth BE, Haskell WL, Whitt MC, Irwin ML, Swartz AM, Strath SJ, O'Brien WL, Bassett DR, Schmitz KH, Emplaincourt PO, Jacobs DR, Leon AS (2000) Compendium of physical activities: an update of activity codes and MET intensities. Med Sci Sports Exerc 32:S498-S516

2. Arbeitsgruppe Epidemiologische Methoden der Deutschen Arbeitsgemeinschaft Epidemiologie (DAE) [German Working Group Epidemiology] (2005) Leitlinien und Empfehlungen zur Sicherung von guter Epidemiologischer Praxis (GEP) - Überarbeitete Fassung nach Evaluation [Guidelines and recommendations for ensuring Good Epidemiological Practice (GEP)-Revised version after evaluation]. Gesundheitswesen 67:217-225

3. Australian Bureau of Statistics (2006) National Health Survey 2004 05: summary of results. Australian Bureau of Statistics, Canberra

4. Baltes PB, Mayer KU (eds) (1999) The Berlin aging study: aging from 70 to 100 . Cambridge University Press, New York

5. Blair SN, Wei M (2000) Sedentary habits, health, and function in older women and men. Am J Health Promot 15:1-8

6. Brownson RC, Baker EA, Housemann RA, Brennan LK, Bacak SJ (2001) Environmental and policy determinants of physical activity in the United States. Am J Public Health 91:1995-2003

7. Brownson RC, Housemann RA, Brown DR, Jackson-Thompson J, King AC, Malone BR, Sallis JF (2000) Promoting physical activity in rural communities - walking trail access, use, and effects. Am J Prev Med 18:235-241

8. Brownson RC, Schmid TL, King AC, Eyler AA, Pratt M, Murayi T, Mayer JP, Brown DR (1998) Support for policy interventions to increase physical activity in rural Missouri. Am J Health Promot $12: 263-266$

9. Centers for Disease Control and Prevention and the Merck Company Foundation (2004) The state of aging and health in America 2004. Centers for Disease Control and Prevention and the Merck Company Foundation, Whitehouse Station

10. Centers for Disease Control and Prevention and the Merck Company Foundation (2007) The state of aging and health in America 2007. Centers for Disease Control and Prevention and the Merck Company Foundation, Whitehouse Station

11. Cerin E, Leslie E (2008) How socio-economic status contributes to participation in leisure-time physical activity. Soc Sci Med 66:2596-2609. doi:10.1016/j.socscimed.2008.02.012

12. Cohen-Mansfield J, Marx MS, Guralnik JM (2003) Motivators and barriers to exercise in an older community-dwelling population. J Aging Phys Act 11:242-253
13. Department for Culture, Media and Sport (2008) Sport workbook (Data from 'Taking Part: The National survey of culture, leisure and sport 2005/06' and 'Taking Part: England's survey of culture, leisure and sport 2006/07'). http://www.culture.gov.uk/reference library/publications/5396.aspx. Accessed 1 August 2009

14. Diehm C, Lange S, Darius H, Pittrow D, von Stritzky B, Tepohl G, Haberl RL, Allenberg JR, Dasch B, Trampisch HJ (2006) Association of low ankle brachial index with high mortality in primary care. Eur Heart J 27:1743-1749. doi:10.1093/eurheartj/ehl092

15. Eynon N, Yamin C, Ben-Sira D, Sagiv M (2009) Optimal health and function among the elderly: lessening severity of ADL disability. Eur Rev Aging Phys Act 6:55-61. doi:10.1007/ s11556-009-0048-7

16. Federal Statistical Office (2007) Demographic change in Germany (Heft 1: Bevölkerungs- und Haushaltsentwicklung im Bund und in den Ländern). Federal Statistical Office, Wiesbaden

17. Frey I, Berg A, Grathwohl D, Keul J (1999) Freiburger Fragebogen zur körperlichen Aktivität-Entwicklung, Prüfung und Anwendung (Freiburger questionnaire on physical activitydesign, validation and application). Soz-Präventivmed 44:55-64

18. Fries J (1996) Physical activity, the compression of morbidity, and the health of the elderly. J R Soc Med 89:64-68

19. getABI Study Group (2002) getABI: German epidemiological trial on ankle brachial index for elderly patients in family practice to detect peripheral arterial disease, significant marker for high mortality. Vasa 31:241-248

20. Grundy SM, Cleeman JI, Daniels SR, Donato KA, Eckel RH, Franklin BA, Gordon DJ, Krauss RM, Savage PJ, Smith SC, Spertus JA, Costa F (2005) Diagnosis and management of the metabolic syndrome - an American Heart Association/National Heart, Lung, and Blood Institute Scientific Statement. Circulation 112:2735-2752. doi:10.1161/circulationaha.105.169404

21. Hara T, Shimada T (2007) Effects of exercise on the improvement of the physical functions of the elderly. J Phys Ther Sci 19:15-26

22. Hollmann W, Strueder HK, Tagarakis CVM, King G (2007) Physical activity and the elderly. Eur J Cardiovasc Prev Rehabil 14:730-739

23. Hovell MF, Hofstetter CR, Sallis JF, Rauh MJD, Barrington E (1992) Correlates of change in walking for exercise - an explanatory analysis. Res Q Exerc Sport 63:425-434

24. Landi F, Onder G, Carpenter I, Cesari M, Soldato M, Bernabei R (2007) Physical activity prevented functional decline among frail community-living elderly subjects in an international observational study. J Clin Epidemiol 60:518-524. doi:10.1016/j.jclinepi. 2006.09.010

25. Laslett P (1991) A fresh map of life: the emergence of the third age. Harvard University Press, Cambridge

26. Lim K, Taylor L (2005) Factors associated with physical activity among older people - a population-based study. Prev Med 40:3340. doi:10.1016/j.ypmed.2004.04.046

27. McDermott AY, Mernitz H (2006) Exercise and older patients: prescribing guidelines. Am Fam Physician 74:437-444

28. Mian OS, Baltzopoulos V, Minetti AE, Narici MV (2007) The impact of physical training on locomotor function in older people. Sports Med 37:683-701

29. Nelson ME, Rejeski WJ, Blair SN, Duncan PW, Judge JO, King AC, Macera CA, Castaneda-Sceppa C (2007) Physical activity and public health in older adults: recommendation from the American College of Sports Medicine and the American Heart Association. Circulation 116:1094-1105

30. Neugarten BL (1974) Age groups in American society and the rise of the young-old. Ann Am Acad Pol Soc Sci 415:187-198

31. Pan SY, Cameron C, DesMeules M, Morrison H, Craig CL, Jiang X (2009) Individual, social, environmental, and physical environmental correlates with physical activity among Canadians: a cross-sectional study. BMC Public Health 9:12. doi:10.1186/1471-2458-9-21 
32. Pratt M, Macera CA, Wang GJ (2000) Higher direct medical costs associated with physical inactivity. Phys Sportsmed 28:63-70

33. Robert Koch Institut (2008) Federal health reporting: health in Germany. Robert Koch Institut, Berlin

34. Rowe N, Bibby H (2007) Active sport. In: Aust R, Vine L (eds) Taking part: the national survey of culture, leisure and sport annual report 2005/2006. Department for Culture, Media and Sport, London, pp 75-83

35. Sallis JF, Hovell MF, Hofstetter CR (1992) Predictors of adoption and maintenance of vigorous physical activity in men and women. Prev Med 21:237-251
36. Skelton D, Young A, Walker A, Hoinville E (1999) Physical activity in later life. Health Education Authority, London

37. Suzman RM, Willis DP, Manton KG (eds) (1992) The oldest old. Oxford University Press, New York

38. Ware JE, Kosinski M, Dewey JE, Gandek B (2001) How to score and interpret single-item health status measures: a manual for users of the SF-8 health survey. Quality Metric Inc, Lincoln

39. Zizzi S, Goodrich D, Wu Y, Parker L, Rye S, Pawar V, Mangone C, Tessaro I (2006) Correlates of physical activity in a community sample of older adults in Appalachia. J Aging Phys Act 14:423-438 